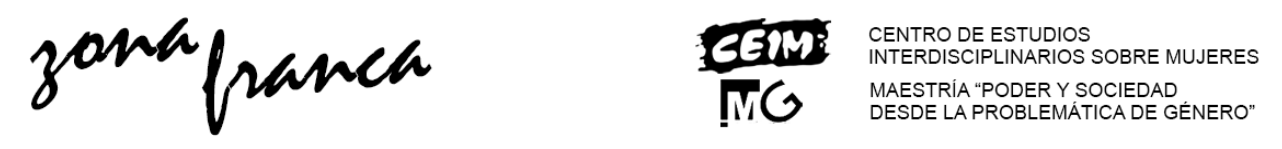

\title{
En memoria de Hilda Habichayn (1934-2021)
}

Murió Hilda Habichayn, una feminista, una mujer de izquierda, (si, profundamente anticapitalista) una gran persona. Profesora de la Universidad de Rosario, será recordada como la impulsora del Centro de Estudios Históricos sobre las Mujeres, hoy denominado Centro de Estudios Interdisciplinario sobre las Mujeres (CEIM) de la Facultad de Humanidades y Artes y por haber creado la primera maestría en estudios de género en América Latina, en 1993.

En efecto, en 1993 se lanzó a la hermosa aventura de la Maestría Poder y Sociedad desde la Problemática del Género, nombre no elegido, sino impuesto después de un ir y venir por CONEAU, una institución que no tenía a nadie con los conocimientos necesarios para evaluarla, pero si para boicotearla.

Era una época en que pocas nos decíamos feministas en la academia e Hilda pagó con creces esa audacia. Más aún si se seguían sosteniendo los ideales de siempre, que implicaban no hacer concesiones al poder. A las pruebas me remito, la Maestría estuvo 3 años sin convalidar su aprobación por el Consejo Superior de Universidad de Rosario.

Como docente de la primera hora puedo contar muchas anécdotas sobre el esfuerzo de sostener este posgrado contra viento y marea, pero prefiero recordar a Hilda por su alegría y empeño en seguir adelante, en las reuniones compartidas, en ese ritual de sacar el monedero antiguo que tenía para pagarnos (así de artesanal era la cosa), en su compromiso con el feminismo.

Tanto ella como su compañero Héctor Bonaparte eran activistas no sólo de la causa del feminismo, sino de la vida que merece vivirse.

Ojalá las y los jóvenes no la olviden, por luchadoras como ella, seguimos teniendo esperanza en la humanidad.

Revista Zona Franca- Centro de estudios interdisciplinario sobre las mujeres (CEIM)- Maestría poder y sociedad desde la problemática de género (MG), Rosario, Argentina. ISSN, 2545-6504 http://zonafranca.unr.edu.ar/index.php/ZonaFranca| Número 29 (2021). 
Hasta la victoria siempre querida Hilda.

Monica Tarducci *

*Instituto de Investigaciones de Estudios de Género. FFyL. UBA. Contacto: latardu@gmail.com

Revista Zona Franca- Centro de estudios interdisciplinario sobre las mujeres (CEIM)- Maestría poder y sociedad desde la problemática de género (MG), Rosario, Argentina. ISSN, 2545-6504 http://zonafranca.unr.edu.ar/index.php/ZonaFrancal Número 29 (2021). 